\title{
Standing Committee on Geology and Geophysics
}

GORDON A. MACDONALD, chairman

Australia

Geology

Geophysics

Canada

Geology

Geophysics

Chile

Geology and

Geophysics

China

Geology and

Geophysics

El Salvador

Geology and

Geophysics

Indonesia

Geology

Geophysics

Japan

Geology

Geophysics

Malaya

Geology and

Geophysics

Mexico

Geology and

Geophysics

New Zealand

Geology

Geophysics

Philippines

Geology and

Geophysics
N. H. FISHER

J. M. RAYNER

G. B. LEECH

J. A. JACOBS

HECTOR FLORES W.

V. C. JUAN

FRITZ DURR

JOHN KATILI

ROBERT W. DECKER

TEIICHI KOBAYASHI

TSUNEJI RIKITAKE

J. B. ALEXANDER

M. MALDONADO-KOERDELL

R. S. Allan

E. I. ROBERTSON

ARTURo AlCARAZ
Bureau of Mineral Resources Canberra

Bureau of Mineral Resources Canberra

Victoria Museum Ottawa

University of British Columbia Vancouver

Universidad de Chile Santiago

National Taiwan University Taipei

Servicio Geologico Nacional
San Salvador

University of Indonesia Bandung

Dartmouth College Hanover

University of Tokyo Tokyo

University of Tokyo Tokyo Geological Survey
Batu Gajah

Instituto Pan-Americano de Geografia e Historia Mexico City

Canterbury University Christchurch

Department of Scientific and Industrial Research Wellington

University of the Philippines Quezon City 
Thailand

Geology and

Geophysics

SAMAN BURAVAS

United States

Hawaii

Geology and Geophysics

Pacific Basin

Geology and

Geophysics

U.S. Trust Territory

Geology and

Geophysics

Charles G. Johnson

Western Pacific High Commission Territories

Geology and

Geophysics

EDWIN L. HAMILTON

J. C. Grover

\section{Royal Department of Mines Bangkok}

GORDON A. MACDONALD
University of Hawaii

Honolulu

Naval Electronics Laboratory San Diego

U.S. Army Engineers Honolulu

Geological Survey Department British Solomon Islands Protectorate 